\title{
Mapping the potential distribution of high artemisinin-yielding Artemisia annua L. (Qinghao) in China with a geographic information system
}

\author{
Linfang Huang, Caixiang Xie, Baozhong Duan and Shilin Chen*
}

\begin{abstract}
Background: Artemisia annua L. is an important source for artemisinin, a potent drug for treating malaria. This study aims to map and predict the potential geographic distribution of A. annua L. in China.

Methods: The Geographic Information System for traditional Chinese medicine (TCM-GIS) was developed and used to map the potential geographic distribution of A. annua L.

Results: Climatic, edaphic and topographic characteristics of A. annua L. microhabitats in Youyang County were mapped to find distribution patterns. The maps identified that certain habitats in the Chongqing region and some potential regions, especially in Guizhou Province, possess similarity indices of $\geq 98 \%$. In particular, high quality microhabitats $A$. annua $\mathrm{L}$. were found in the Wuling mountains region.
\end{abstract}

Conclusion: The present study demonstrates a GIS approach to predict potential habitats for A. annua L. TCM-GIS is a powerful tool for assessing bioclimatic suitability for medicinal plants.

\section{Background}

Artemisia annua L. (Qinghao, Annual Wormwood) is a strongly fragrant, annual herbaceous plant used in Chinese medicine [1]. A. апnua $\mathrm{L}$. is the only natural botanical source for artemisinin (Qinghaosu) [2,3] and a potential source for essential oils for the perfume industry [4]. A. annua L. is now cultivated in China, Vietnam, India, Romania, Kenya and Tanzania [5]. Artemisinin, an endoperoxide sesquiterpene lactone in the aerial parts of A. апииа L., is more efficacious, faster and less toxic than chloroquine in treating malaria. In addition, artemisinin is a potent anti-cancer agent, a possible antibacterial agent as well as a natural pesticide [6,7]. Chemical and biological synthesis of artemisinin is still under development due to poor yields [8-11]. Therefore, wild or cultivated $A$. апnиa $\mathrm{L}$. is a major source for artemisinin $[2,3,12]$.

The artemisinin content is highly dependent on plant ecotypes, ecological interactions, seasonal and geographic variations [13-18]. In fact, artemisinin is absent in

* Correspondence: slchen@implad.ac.cn

${ }^{1}$ Institute of Medicinal Plant Development, Chinese Academy of Medical Sciences and Peking Union Medical College, Beijing 100193, China

Full list of author information is available at the end of the article some A. апnиа L. Artemisinin was first isolated in China and some Chinese germplasm has relatively higher artemisinin levels than those of Europe, North America, East Africa and Australia [2,13,16,17,19,20]. In Youyang County, Chongqing, China, the hometown of $A$. аnnua L., the plants have high (0.9\%) levels of artemisinin. In 2006 the county became a national protected geographic area recognized by the General Administration of Quality Supervision, Inspection and Quarantine of China [21]. As the demand for artemisinin remains high around the world, finding suitable geographic regions for $A$. annua $\mathrm{L}$. is a critical research area for the World Health Organization [22].

The geographic information system (GIS) technology manages geographic information with applications for various fields such as natural resources, transportation planning, environmental studies and vegetation distribution studies [23-26]. Recently updated, the geographic information system for traditional Chinese medicine (TCM-GIS) captures, stores, analyzes and displays geographically referenced information to analyze genetic, ecological and geographic patterns of the spatial distribution of a target species. Using the TCM-GIS, our previous 
studies analyzed the potential habitats and distributions of Chinese medicinal plants such as Glycyrrhiza uralensis Fisch., Panax quinquefolium and Panax ginseng [27-29]. The present study aims to characterize the eco-environmental conditions in the A. апnиa L. production areas in Youyang County and predict the potential distributions of $A$. апnиa $\mathrm{L}$. with a high artemisinin-yielding potentials.

\section{Methods}

\section{Data collection}

The spatial distribution of $A$. annua $\mathrm{L}$. was based on the following four sources: (1) the flora of China [30]; (2) scientific literature concerning the geographic distribution of A. annua L. in China [31]; (3) the Chinese Virtual Herbarium $(\mathrm{CVH})$ [32], (4) germplasm accessions from the Sharing Information System for Chinese Medicinal Plant Germplasm Resources [33]; (5) field data of wild $A$. annua L. and interviews in Youyang County in 2008. Due to the excellent quality of $A$. annua $\mathrm{L}$. from the habitats in Youyang County [31,34-36], a total of 180 accessions of $A$. аппиа L. germplasm were collected and used in the present study.

The potential distribution mapping program TCM-GIS and geo-referenced datasets were used to develop ecoadaptation models. The TCM-GIS package included three databases, namely (1) a basic geographic information database including digital line graphics and a digital elevation model (scale: 1:1,000,000), (2) a soil database (scale: 1:4,000,000), (3) and a climate database (mean values between 1971 and 2000). All three databases were used for spatial analysis and model calibration.

Raster and vector are two main data models in the TCM-GIS. Raster layers $\left(1 \times 1 \mathrm{~km}^{2}\right.$ resolution) were used for the eco-environmental analysis and cluster analysis. Vector layers were used to derive and identify the spatial extent and location of suitable habitats through overlay analysis. Moreover, global positioning system data on the locations of the 180 accessions were obtained for villages such as Banqiao, Zhongduo, Mawang and Nanmu and used in the TCM-GIS analysis (Figure 1).

In the present study, 14 eco-environmental variables were chosen for the predication of spatial distribution in Youyang County. These variables, namely (1) average temperature in January (ATJA), (2) average temperature in February (ATF), (3) average temperature in March (ATM), (4) average temperature in April (ATAP), (5) average temperature in May (ATMA), (6) average temperature in June (ATJ), (7) average temperature in July (ATJU), (8) average temperature in August (ATA), (9) average annual temperature (AAT), (10) annual sunshine time (AST), (11) total annual precipitation (TAP), (12) relative humidity (RH), (13) altitude (AL), (14) and soil properties (SP), were classified into three categories: topography, climate and edaphology (Table 1).

\section{Data analysis}

An optimal range was established by identifying minima and maxima for eco-environmental variables (e.g. elevation and temperature) at sample collection sites. The $A$. апnи $\mathrm{L}$. macro-habitats were characterized by examining the mean, minimal and maximal values, standard deviation (SD), standard error (SE), and coefficient of variation $(\mathrm{CV})$ of these variables (Table 2). Prior to distance analysis, we normalized the raster grid data representing each variable. We derived the mean absolute deviation using the following equation:

$$
s_{f}=\frac{1}{n}\left(\sum_{k=1}^{n}\left|x_{k f}-m_{f}\right|\right)
$$

where $x_{\mathrm{kf}}$ was the measured values of the variable $f$ and $\mathrm{m}_{\mathrm{f}}$ is the mean for the variable $\mathrm{f}$. For the determination of similarity between grid data and eco-factor ranges, the statistical distance was calculated with the Minkowski distance equation [37]:

$$
d_{i j}=\left[\sum_{k=1}^{n}\left|x_{i k}-x_{j k}\right|^{2}\right]^{\frac{1}{2}}
$$

which is a generalization of the Euclidean distance and Manhattan distance; in general the shorter the distance, the greater the similarity. The comprehensive similarity index (SI) of each factor layer was calculated with an overlay analysis with various weighting values. Finally, maps with two ranks of predictive distributions were generated, followed by a grid-based spatial cluster analysis, vector-based overlaying, intersection analysis and an area calculation (Figures 2, 3, 4, Table 3).

The most favorable region for $A$. annua $\mathrm{L}$. growth is one that has an SI range of $99 \%-100 \%$, while the secondmost favorable region is one that has an SI range of 98\%$99 \%$.

\section{Results and Discussion}

\section{Eco-environmental preferences}

The climatic, edaphic and topographic characteristics of known A. апnиа L. habitats are listed in Table 2. While low $\mathrm{CV}$ values for RH (CV: 0.33), TAP (1.28), AST (3.33), ATJU (4.60), AAT (4.69), ATA (6.23), ATJ (6.77) and ATMA (6.81) suggested that these could be the major limiting factors affecting the distribution of high quality A. annua L., high CV values for AL (29.79), ATJA (21.46) and ATF (21.43) suggested otherwise. According to the $\mathrm{CV}$ values, weighting value for each parameter was divided into levels I (0.15), II (0.08), III (0.06) and IV 


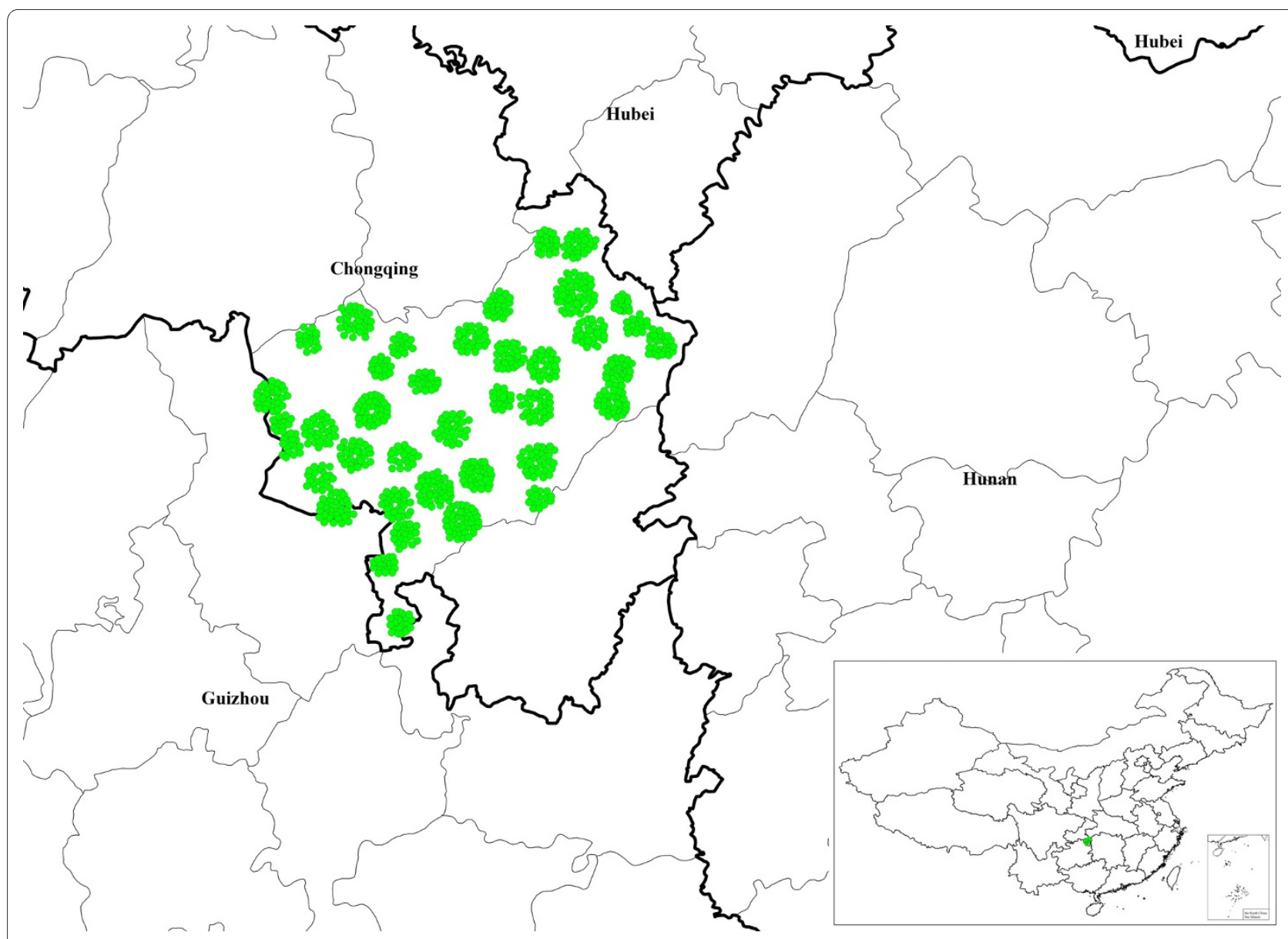

Figure 1 Spatial distribution of $A$. annua L. germplasm collection sites as mapped with the TCM-GIS.

(0.03) and weighting values should add up to one. In addition, datasets of eco-factors from known habitats in Youyang County were as follows: ATJA $=1.2-5.6^{\circ} \mathrm{C}$, ATF $=2.0-6.0^{\circ} \mathrm{C}, \mathrm{ATM}=4.0-10.0^{\circ} \mathrm{C}$, ATAP $=10.0-16.0^{\circ} \mathrm{C}$, $\mathrm{ATMA}=14.0-20.0^{\circ} \mathrm{C}, \mathrm{ATJ}=18.0-24.0^{\circ} \mathrm{C}, \mathrm{ATJU}=21.6-$ $27.3^{\circ} \mathrm{C}, \mathrm{ATA}=20.0-26.0^{\circ} \mathrm{C}, \mathrm{AAT}=15.9-21.0^{\circ} \mathrm{C}, \mathrm{AST}=$ $1048-1200 \mathrm{~h}, \mathrm{TAP}=1169-1267 \mathrm{~mm}, \mathrm{RH}=79.2-80.6 \%, \mathrm{AL}$ $=498-1010 \mathrm{~mm}$. Soil types were mainly yellow soil, yellow sandy soil, limestone soil, paddy soil and brown soil with $\mathrm{pH}$ value at 6-7 and organic matter content $\geq 1.3 \%$. Thus, we assumed that these conditions were optimal for the growth of high artemisinin-yielding A. annua L.

A. annua L. is a short-day plant. Non-juvenile plants are very responsive to short photoperiodic stimuli and flower about two weeks after induction. They require about 1000 hours of sunlight per year. Our results suggest that annual sunlight time is a critical factor for the growth of $A$. annua L., which is consistent with previous studies [5,38]. Previous findings that A. annua L. requires a strict watering regime during the preliminary growth stages $[5,39]$ are also consistent with our results.

\section{Predictive maps}

Figures 2 and 3 are the maps derived from the TCM-GIS analyses. The predicted areas were primarily located in the Wuling Mountain region in central China, covering Guizhou, Chongqing, Hunan, Hubei and Sichuan (25 $14^{\prime}-$ $31^{\circ} 38^{\prime} \mathrm{N}$ to $\left.104^{\circ} 31^{\prime}-111^{\circ} 51^{\prime} \mathrm{E}\right)$. The predicted habitat density was high in northeastern Guizhou, southeastern Chongqing, northwestern Hunan, southwestern Hubei and parts of southern Sichuan.

The total favorable regions (SI 98\%-99\%) made up $1.60 \%$ of China's total land area covering 162 counties and cities (a total of $60,292 \mathrm{~km}^{2}$ ), among which Guizhou took the lead with $31,150 \mathrm{~km}^{2}$ including 68 counties and cities. The most favorable region for A. annua L. (SI 99\%-100\%) was in the 58 counties and cities in Guizhou Province with a predicted area of $54,350 \mathrm{~km}^{2}$. The second largest predicted area $\left(14,330 \mathrm{~km}^{2}\right)$ was in the 12 counties and cities in Chongqing, followed by Hunan, Hubei and Sichuan (Figure 4). The counties and cities with significant areas of potential habitat are listed in Table 3. The data indicated that Youyang County contained the largest 
Table 1: Environmental factors used in this study.

\begin{tabular}{|c|c|c|}
\hline Category & Variables & Abbreviation \\
\hline \multirow[t]{12}{*}{ Climate } & Average temperature in January $\left({ }^{\circ} \mathrm{C}\right)$ & ATJA \\
\hline & Average temperature in February $\left({ }^{\circ} \mathrm{C}\right)$ & ATF \\
\hline & Average temperature in $\operatorname{March}\left({ }^{\circ} \mathrm{C}\right)$ & ATM \\
\hline & Average temperature in April $\left({ }^{\circ} \mathrm{C}\right)$ & ATAP \\
\hline & Average temperature in May $\left({ }^{\circ} \mathrm{C}\right)$ & ATMA \\
\hline & Average temperature in June $\left({ }^{\circ} \mathrm{C}\right)$ & ATJ \\
\hline & Average temperature in July $\left({ }^{\circ} \mathrm{C}\right)$ & ATJU \\
\hline & Average temperature in August $\left({ }^{\circ} \mathrm{C}\right)$ & ATA \\
\hline & Average Annual temperature $\left({ }^{\circ} \mathrm{C}\right)$ & AAT \\
\hline & Annual sunshine time $(h)$ & AST \\
\hline & Total annual precipitation $(\mathrm{mm})$ & TAP \\
\hline & Relative humidity (\%) & $\mathrm{RH}$ \\
\hline Topography & Altitude $(\mathrm{m})$ & AL \\
\hline Edaphology & Soil properties & SP \\
\hline
\end{tabular}

favorable area with more than $4000 \mathrm{~km}^{2}$. Unexpectedly, the total predicted areas in Wuchuan and Zunyi Counties in Guizhou exceeded $2000 \mathrm{~km}^{2}$.

One of the world's largest artemisinin manufacturers and its affiliates operate $A$. апnиa $\mathrm{L}$. farms in the Chongqing Wulingshan Mountain Range [40,22]. Apart from this, Guizhou may be another important region for A. annua L. cultivation, particularly in the northeastern part of the province. Our model predicted that $13 \%$ of this area is potential $A$. annua L. habitats [41,42]. Our model did not predict Guangxi Province, known for its habitats of $A$. апnиa $\mathrm{L}$. of relatively low quality, as a region for $A$. апnиa $\mathrm{L}$. cultivation possibly due to the subtropical climate, low altitude and red soil in Guangxi which are very different from those in other $A$. аппиа $\mathrm{L}$. regions in China [9].

Interviews with the locals suggest that the Guizhou region and Youyang County have comparative advantages

Table 2: Summary of eco-environmental characteristics from known $A$. annua L. habitats $(n=180)$.

\begin{tabular}{lllllll}
\hline Variables & Mean & SE & CV\% & SD & Range & Weight \\
\hline ATJA $\left({ }^{\circ} \mathrm{C}\right)$ & 3.95 & 0.005 & 21.46 & 0.849 & $1.2-5.6$ & 0.03 \\
$\operatorname{ATF}\left({ }^{\circ} \mathrm{C}\right)$ & 4.1 & 0.005 & 21.43 & 0.765 & $2.0-6.0$ & 0.03 \\
$\operatorname{ATM}\left({ }^{\circ} \mathrm{C}\right)$ & 8.50 & 0.005 & 13.36 & 1.136 & $4.0-10.0$ & 0.06 \\
$\operatorname{ATAP}\left({ }^{\circ} \mathrm{C}\right)$ & 13.35 & 0.007 & 10.45 & 1.39 & $10.0-16.0$ & 0.06 \\
$\operatorname{ATMA}\left({ }^{\circ} \mathrm{C}\right)$ & 17.92 & 0.006 & 6.81 & 1.22 & $14.0-20.0$ & 0.08 \\
$\operatorname{ATJ}\left({ }^{\circ} \mathrm{C}\right)$ & 21.23 & 0.007 & 6.77 & 1.43 & $18.0-24.0$ & 0.08 \\
$\operatorname{ATJU}\left({ }^{\circ} \mathrm{C}\right)$ & 25.30 & 0.06 & 4.60 & 1.164 & $21.6-27.3$ & 0.08 \\
$\operatorname{ATA}\left({ }^{\circ} \mathrm{C}\right)$ & 23.56 & 0.08 & 6.23 & 1.469 & $20.0-26.0$ & 0.08 \\
$\operatorname{AAT}\left({ }^{\circ} \mathrm{C}\right)$ & 19.32 & 0.05 & 4.69 & 0.907 & $15.9-21.0$ & 0.08 \\
$\operatorname{AST}(\mathrm{h})$ & 1118.00 & 0.21 & 3.33 & 37.32 & $1048-1200$ & 0.08 \\
$\operatorname{TAP}(\mathrm{mm})$ & 1209.00 & 0.09 & 1.28 & 15.46 & $1169-1267$ & 0.08 \\
$\operatorname{RH}(\%)$ & 79.85 & 0.02 & 0.33 & 2.63 & $79.2-80.6$ & 0.15 \\
$\operatorname{AL}(\mathrm{m})$ & 771.03 & 1.28 & 29.79 & 229.73 & $498-1010$ & 0.03 \\
$\operatorname{SP*}$ & & & & & 0.08
\end{tabular}

*Indication of five soil types: yellow soil, yellow sandy soil, limestone soil, paddy soil and brown soil; pH: 6-7; organic matter content $\geq 1.3 \%$ 


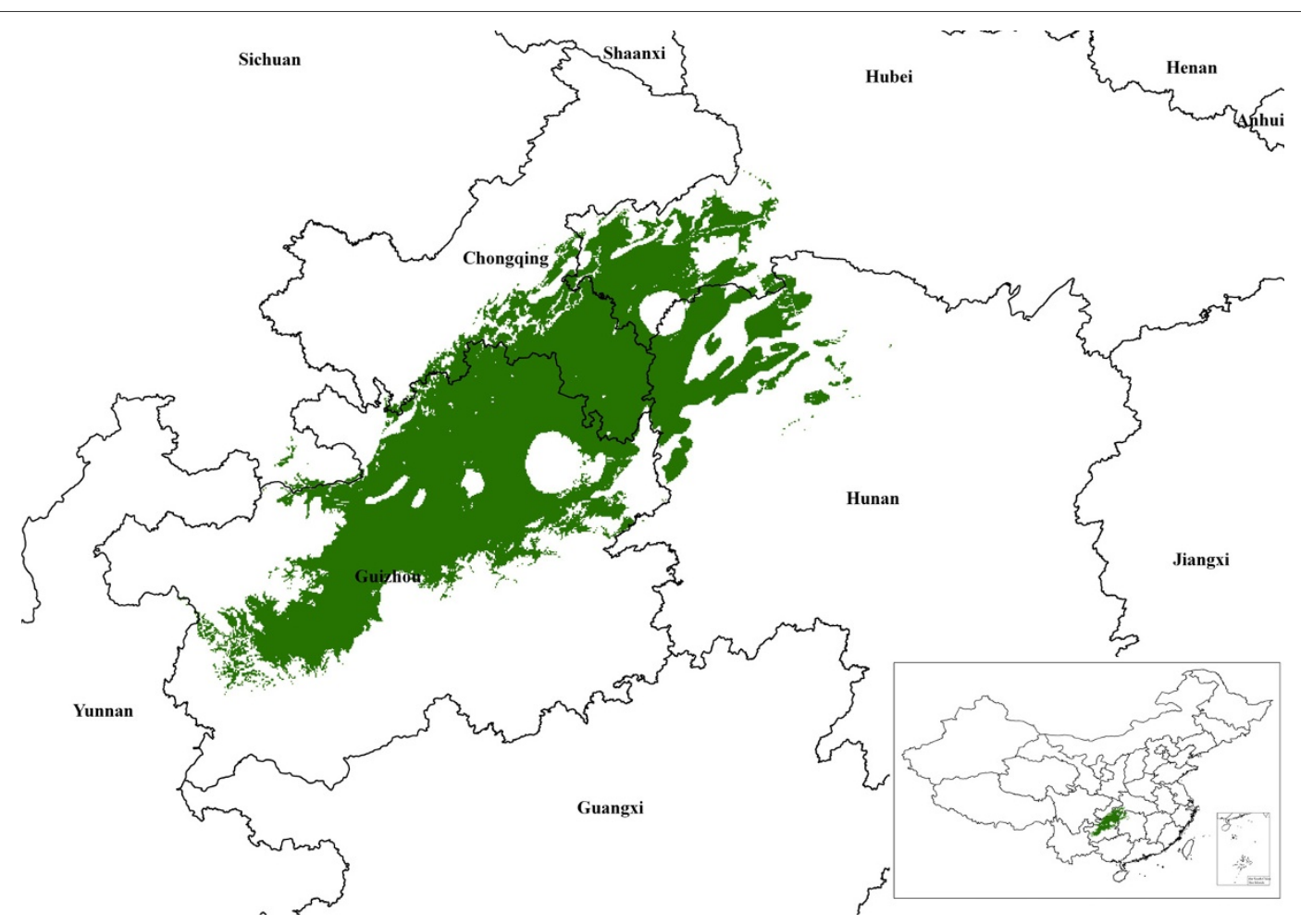

Figure 2 Distribution of suitable A. annua L. production areas in China with a similarity index (SI) of 99-100\%

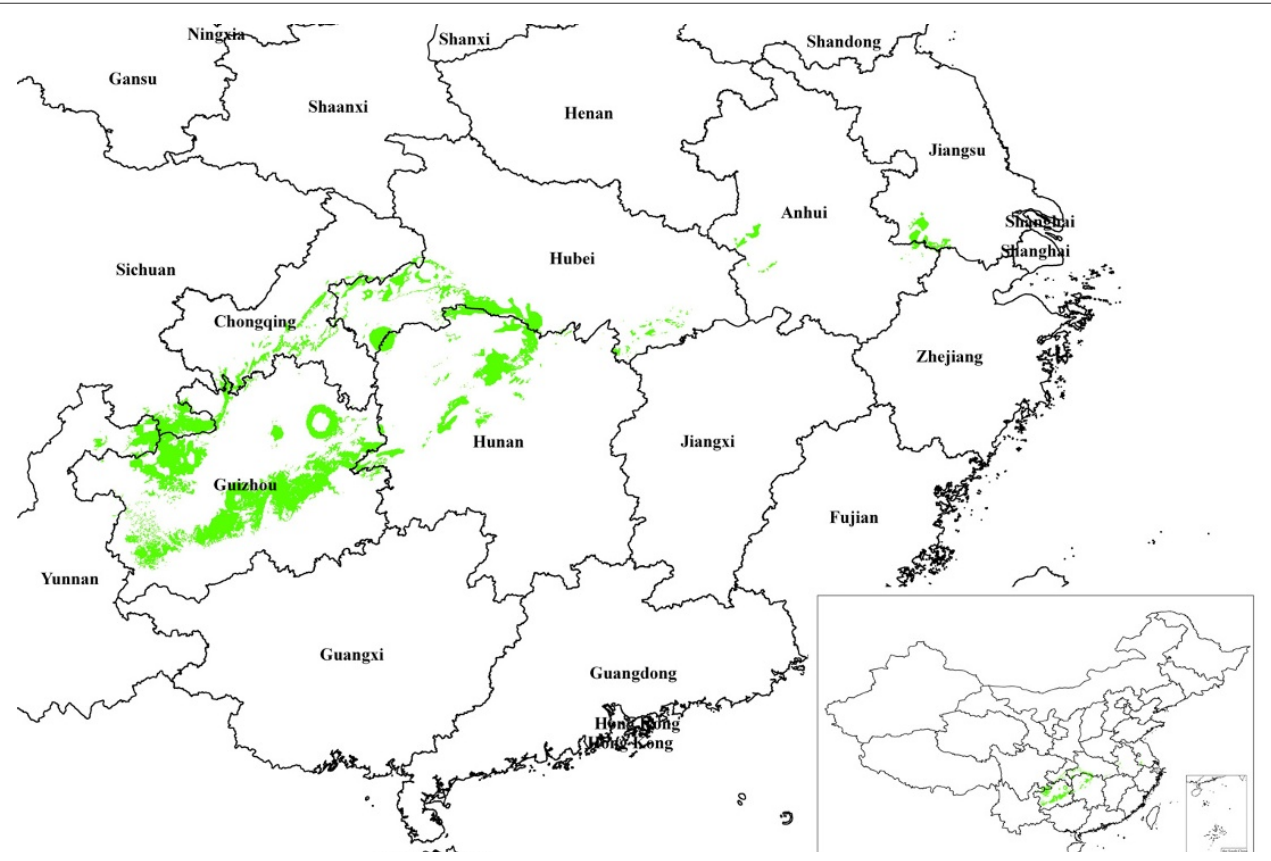

Figure 3 Distribution of suitable A. annua L. production areas in China with a similarity index (SI) of 98-99\%. 


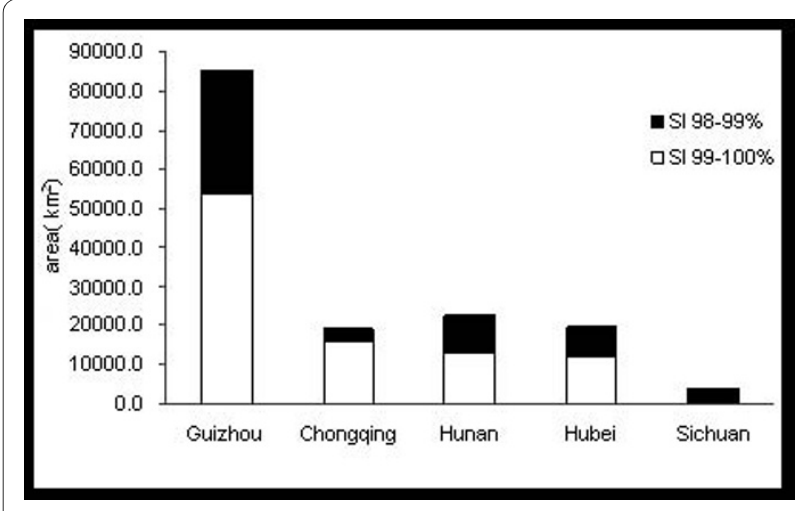

Figure 4 Suitable regions for $A$. annua L. production with a similarity index (SI) of $\geq 98 \%$

for A. annua L. growth with a high-yield variety and minimal pests. Furthermore, the northeastern Guizhou is home to wild populations of $A$. annua $\mathrm{L}$. which may be an alternative source for artemisinin.

Using the TCM-GIS, we aimed to determine the optimal ecological factors from known habitats and the results showed that RH, TAP, AST, STJU, AAT and SP were important limiting factors. We also aimed to map the distribution of potential regions for the development of $A$. аппиа L. in China based on selected climatic, soil and topographical values. Using bioclimatic similarity theory and the TCM-GIS, we predicted the potential growing areas at the county level, particularly in northeastern Guizhou Province. The TCM-GIS is adequate for predicting and identifying potential areas for $A$. anпиа $\mathrm{L}$. cultivation.

Using a higher resolution raster and vector spatial databases, we improved the resolution of species distribution considerably on the national surveys conducted in the 1960s, 1970s and 1980s. While most of the survey data were based largely on personal experiences and rough estimates, the model used in the present study is relatively objective.

\section{Conclusion}

The present study demonstrates a GIS approach to predict the potential habitats for A. апnиа L. TCM-GIS is a powerful tool for assessing bioclimatic suitability for medicinal plants.

Table 3: Major A. annua L. regions with similarity index (SI) of 99\%-100\%.

\begin{tabular}{|c|c|c|c|c|c|}
\hline $\begin{array}{l}\text { County/City, } \\
\text { Province* }\end{array}$ & $\begin{array}{l}\text { Suitable areas } \\
\text { km2 }\end{array}$ & $\begin{array}{l}\text { Suitable areas } \\
\%\end{array}$ & $\begin{array}{l}\text { County/City, } \\
\text { Province }\end{array}$ & $\begin{array}{l}\text { Suitable areas } \\
\text { km2 }\end{array}$ & $\begin{array}{l}\text { Suitable areas } \\
\%\end{array}$ \\
\hline $\begin{array}{l}\text { Youyang, } \\
\text { Chongqing }\end{array}$ & 4386 & 92 & Hefeng, Hubei & 1225 & 46 \\
\hline $\begin{array}{l}\text { Xiushan, } \\
\text { Chongqing }\end{array}$ & 1419 & 63 & Enshi, Hubei & 2038 & 55 \\
\hline $\begin{array}{l}\text { Wulong, } \\
\text { Chongqing }\end{array}$ & 1290 & 48 & Zunyi, Guizhou & 3264 & 70 \\
\hline $\begin{array}{l}\text { Qiangjiang, } \\
\text { Chongqing }\end{array}$ & 2286 & 97 & Zhijin, Guizhou & 1594 & 62 \\
\hline $\begin{array}{l}\text { Pengshui, } \\
\text { Chongqing }\end{array}$ & 3182 & 87 & $\begin{array}{l}\text { Zhengan, } \\
\text { Guizhou }\end{array}$ & 1590 & 67 \\
\hline $\begin{array}{l}\text { Zhangjiajie, } \\
\text { Hunan }\end{array}$ & 1388 & 58 & Yanhe, Guizhou & 1471 & 65 \\
\hline Yongshun, Hunan & 1863 & 52 & Xixiu, Guizhou & 1387 & 90 \\
\hline Shangzhi, Hunan & 1966 & 61 & $\begin{array}{l}\text { Wuchuan, } \\
\text { Guizhou }\end{array}$ & 2119 & 82 \\
\hline Longshan, Hunan & 2017 & 69 & Tongzi, Guizhou & 1579 & 53 \\
\hline Baojing, Hunan & 1235 & 77 & $\begin{array}{l}\text { Shuiyang, } \\
\text { Guizhou }\end{array}$ & 1463 & 62 \\
\hline Xuanen, Hubei & 1909 & 74 & & & \\
\hline $\begin{array}{l}\text { Xianfengshi, } \\
\text { Hubei }\end{array}$ & 2257 & 96 & & & \\
\hline Lichuan, Hubei & 2266 & 52 & $\begin{array}{l}\text { Others are } \\
\text { omitted }\end{array}$ & & \\
\hline
\end{tabular}

*Areas smaller than $1400 \mathrm{~km}^{2}$ are not listed. 


\section{Abbreviations}

TCM-GIS: traditional Chinese medicine geographic information system; GIS: geographic information system; SI: similarity index; SD: standard deviation; SE: standard error; CV: coefficient of variation; ATJA: average temperature in January; ATF: average temperature in February; ATM: average temperature in March; ATAP: average temperature in April; ATMA: average temperature in May; ATJ: average temperature in June; ATJU: average temperature in July; ATA: average temperature in August; AAT: average annual temperature; AST: annual sunshine time; TAP: total annual precipitation; RH: relative humidity; AL: altitude; SP: soil properties; CVH: Chinese Virtual Herbarium.

\section{Competing interests}

The authors declare that they have no competing interests.

\section{Authors' contributions}

LFH, SLC and CXX designed the study and performed the analyses. BZD helped with data analysis. All authors wrote the manuscript. All authors read and approved the final version of the manuscript.

\section{Acknowledgements}

The authors would like to thank the National Natural Science Foundation of China for its support through project No. 3050081

\section{Author Details}

Institute of Medicinal Plant Development, Chinese Academy of Medical Sciences and Peking Union Medical College, Beijing 100193, China

Received: 23 November 2009 Accepted: 17 May 2010

Published: 17 May 2010

\section{References}

1. Wang CW: The forests of China: with a survey of grassland and desert vegetation. In Maria Moors Cabot Foundation Publication Volume 5. Cambridge Massachusetts: Harvard University; 1961:155-164.

2. Jain DC, Mathur AK, Gupta MM, Singh AK, Verma RK, Gupta AP, Kumar S: Isolation of high artemisinin-yielding clones of Artemisia annua. Phytochemistry 1996, 5:993-1001.

3. Klayman DL: Qinghaosu (artemisinin): an antimalarial drug from China. Science 1985, 228:1049-1055.

4. Simon JE, Charles E, Cebert L, Grant J, Janick J, Whipkey A: Artemisia annua L: a promising aromatic and medicinal. In Advances in New Crops: Proceeding of the First National Symposium New Crops: Research, Development, Economics Portland: Timber Press, Incorporated 1990:522-526.

5. World Health Organization: WHO monograph on good agricultural and collection practices (GACP) for Artemisia annua L. Geneva 2006.

6. Efferth T, Dunstan H, Sauerbrey A, Miyachi H, Chitambar CR: The antimalarial artesunate is also active against cancer. Int J Oncol 2001, 18:767-773.

7. Kumar S, Khanuja SPS, Kumar TRS, Jain DC, Srivastava S, Bhattacharya AK, Saikia D, Shasany AK, Darokar MP, Sharma RP: Method for the use of alpha arteether as an anti-bacterial and anti-fungal agent. US Patent 61274052000

8. Avery MA, Chong WKM, Jennings-White C: The total synthesis of (+)Artemisinin and (+)-9-Desmethylartemisinin. Tetrahedron Lett 1987, 28:4629-4632

9. Ravindranathan T, Kumar MA, Menon RB, Hiremath SV: Stereoselective synthesis of artemisinin. Tetrahedron Lett 1990, 31:755-758.

10. Van Geldre E, Vergauwe A, Eeckhout E Van den: State of art of the production of the antimalarial compound artemisinin in plants. Plant Mol Biol 1997, 33:199-209.

11. Chen DH, Li GF, Ye HC: Expression of a chimeric farnesyl diphosphate synthase gene in Artemisia annua L. transgenic plants via Agrobacterium tumefaciens-mediated transformation. Plant Sci 2000, 155:179-185.

12. Kumar S, Gupta SK, Singh P, Bajpai P, Gupta MM, Singh D, Gupta AK, Ram G, Shasany AK, Sharma S: High yields of artemisinin by multi-harvest of Artemisia annua crops. Ind Crops Prod 2004, 1:77-90.

13. Delabays N, Benakis A, Collet G: Selection and breeding for high artemisinin (Qinghaosu) yielding strains of Artemisia annua. Acta Hort (ISHS) 1993, 330:203-208.
14. Liersch R, Soicke H, Stehr C, Tullner HU: Formation of artemisinin in Artemisia annua during one vegetation period. Planta Med 1986, 52:387-390

15. Singh A, Vishwakarma RA, Husain A: Evaluation of Artemisia annua strains for higher artemisinin production. Planta Med 1988, 64:475-476.

16. Charles DJ, Simon JE, Wood KV, Heinstein P: Germplasm variation in artemisinin content of Artemisia annua using an alternative method of artemisinin analysis from crude plant extracts. J Nat Prod 1990, 53:157-159

17. Woerdenbag HJ, Pras N, Chan NG, Bang BT, Bos R, van Uden W, Van YP, van Boi NV, Batterman S, Lugt CB: Artemisinin related sesquiterpenes and essential oil in Artemisia annua during a vegetation period in Vietnam. Planta Med 1994, 60:272-275.

18. Gupta SK, Singh P, Bajpai P, Ram G, Singh D, Gupta MM, Jain DC, Khanuja SPS, Kumar S: Morphogenetic variation for artemisinin and volatile oil in Artemisia annua. Ind Crops Prod 2002, 16:217-224.

19. Trigg El: Qinghaosu (artemisinin) as an antimalarial drug. Econ Med Plant Res 1989, 3:19-55.

20. Klayman DL, Lin AJ, Acton N, Scovill JP, Hoch JM, Milhous WK, Theoharides $A D$, Dobek AS: Isolation of artemisinin (qinghaosu) from Artemisia annua growing in the United States. J Nat Prod 1984, 47:715-717.

21. Genearal Administration of Quality Supervision, Inspection and Quarantine of the People's Republic of China [http://kjs.agsiq.gov.cn/ xxgkml/ywxx/dlbzcpbh/dlbzcpzybzzcdj/bsjg/200710/ t20071012 44016.htm]

22. World Health Organization Global Malaria Programme: Proceedings of the Meeting on the production of artemisinin and artemisinin-based combination therapies: 6-7 June 2005; Arusha Global Malaria Programme; 2006.

23. Goodchild MF: Geographic information systems and science: today and tomorrow. Procedia: Earth and Planetary Science 2009, 1:1037-1043.

24. Segura S, Coppens d'Eeckenbrugge G, Lòpez L, Grum M, Guarino L: Mapping the potential distribution of five species of Passiflora in Andean countries. Genet Resour Crop Evol 2003, 12:555-566.

25. Chen SL, Suo FM, Han JP, Xie CX, Yao H, Li XW, Li Y, Wei JH: Analysis on ecological suitability and regionalization of traditional Chinese medicinal materials. Chin Tradit Herb Drugs 2007, 38:481-487.

26. Smith-Ramirez C, Diaz I, Pliscoff P, Valdovinos C, Mendez MA, Larrain J, Samaniego H: Distribution patterns of flora and fauna in southern Chilean coastal rain forests: Integrating natural history and GIS. Biodivers and Conserv 2007, 16:2627-2648.

27. Wang JY, Zhao RH, Sun CZ, Chen SL Liu SQ, Wei JH, Xiao XX, Zhou YQ: Suitability evaluation of Glycyrrhiza Uralensis Fisch.'s distributive area based on TCMGIS. Mod Chin Med 2006, 8:4-8.

28. Chen SL, Zhou YQ, Xie CX, Zhao RH, Sun CZ, Wei JH, Liu SQ, Gao WW: Suitability evaluation of Panax quinquefolium producing area based on TCMGIS. Zhongguo Zhong Yao Za Zhi 2008, 33:741-745.

29. Wang Y, Wei JH, Chen SL, Sun CZ, Zhao RH, Liu SQ, Xiao XX, Wang JY, Zhou YQ: Analysis of Panax Ginseng' producing area based on TCMGIS. AsiaPacific Trad Med 2006, 6:73-78.

30. Academiae Sinicae Edita: Flora Reipublicae Popularis Sinicae Volume 76. Issue 2 Beijing: Science Press; 1989:62-65.

31. Zhong GY, Zhou HR, Ling Y, Hu M, Zhao PP: Investigation on ecological environment and quantitative analysis of Artemisinin of Sweet Wormwood (Artemisia annua). Chin Med Mat 1998, 29:264-267.

32. The Chinese Virtual Herbarium (CVH) [http://www.cvh.org.cn]

33. Germplasm Accessions From the Sharing Information System for Chinese Medicinal Plant Germplasm Resources [http://www.tcmresources.com/IS/querymain.asp]

34. Yang SP, Yang X, Huang JG, Ding DR: Advances in researches on Artemisinin production. J Trop Subtrop Bot 2004, 12:189-194.

35. Xu XY, Zheng YM, Fu SQ, Han YM, Yang YH: Studies on HPLC Fingerprint of A rtemisia annua L. from Chongqing. Lishizhen Med Mater Med Res 2009, 20:1188-1189.

36. Xia ZZ: Studies on the methods for assay of artemisinin in Artemisia annual L. and its semi-synthetic derivatives. In Master thesis Chongqing Medical University, School of Pharmaceutical Sinence; 2006.

37. He YQ: Multivariate Statistical Analysis Beijing: China Renmin University Press; 2004.

38. Purdue University Annual Wormwood (Artemisia annua L.) [http:// www.hort.purdue.edu/newcrop/cropfactsheets/artemisia.pdf 
39. Wei X, Li F, Xu CQ, Fu XH, Huang ZF: Study on biological characteristics of Artemisia annua L. Guihaia 1997, 17:166-168.

40. Holley Pharmaceuticals Company [http://holleypharma.com/page/ meuf/Holley Pharmaceuticals.html]

41. Zhou AA, Zhen WX, Ge FH: Determination of artemisinin in Artemisia annuna by HPLC-ELSD. Zhong Yao Cai 2006, 29:242-245.

42. Wang $Y L$, Zhang L, Zhang HM: Determination of artemisinin in Artemisia annua from different habitats in Changde region Hunan province. Pharmaceut care Res 2007, 5:381-382.

doi: 10.1186/1749-8546-5-18

Cite this article as: Huang et al., Mapping the potential distribution of high artemisinin-yielding Artemisia annua L. (Qinghao) in China with a geographic information system Chinese Medicine 2010, 5:18

Submit your next manuscript to BioMed Central and take full advantage of:

- Convenient online submission

- Thorough peer review

- No space constraints or color figure charges

- Immediate publication on acceptance

- Inclusion in PubMed, CAS, Scopus and Google Scholar

- Research which is freely available for redistribution

Submit your manuscript at www.biomedcentral.com/submit 